\title{
The Opening of the Insolvency Procedure: Theory v Practice
}

\author{
By Lavinia-Olivia Iancu*
}

\begin{abstract}
The exit from the market of debtors who no longer deal with outstanding payments is legally regulated in most countries around the world. The first modern regulation of the insolvency procedure in Romania was made in 1995 and has suffered many modifications to date that are intended to keep the insolvency procedure in direct connection with socioeconomic reality. The special attention paid to this by insolvency lawmakers, but also its continued development over 20 years, requires a clear procedure for all parties involved. The opening of insolvency proceedings is accessible to debtors who recognise their financial difficulties, but also to creditors under certain conditions expressly lay down by the Insolvency Law. Although the legal text in a first reading seems to be lacking in ambiguous interpretations, its application in practice has raised a number of difficulties, resulting in completely different jurisprudence. The unit of jurisprudence in legal matters is an imperative of any state. The lack of consistency of judicial practice generates an undesirable phenomenon, the insecurity of the legal circuit translated into the decline of the Romanian citizens' confidence in the act of justice.
\end{abstract}

Keywords: Insolvency; Opening of the procedure; Theory versus practice

\section{Introduction}

Let us imagine a spider web built in a tree. Although it seems solid, the cobweb, reinforced in several points that cross each other, is far from being indestructible. It must withstand natural phenomena such as rain, wind or intervention by mankind or animals. The web can be destroyed to a lesser or greater degree, the time of remaking it is proportional to its degree of destruction but various factors are also essential such as the size of the spider, its ability and speed when building the web, and its social activity.

The size of spiders varies; the smallest Patu digua is only $0.37 \mathrm{~mm}$ in size and the biggest - Theraphosa blondi is $90 \mathrm{~mm}$. Small-sized spiders spend less time building their webs and as a paradox, their cobweb is very big compared to their own size. The big spiders, although investing a lot of time in weaving their web, do not display the same performance as the small ones in respect of the spider/web size ratio. And speaking of the size of the cobweb, I must mention the social spiders named Anelosimus eximius, who live in colonies up to 50,000 individuals. In 2007, in Texas, in the Tawakoni natural reserve, a huge spider web of approximately 180 meters was discovered ${ }^{1}$.

I have stated that the spider's social activity influences the building/repairing

\footnotetext{
* Dr of Law, Lecturer, Faculty of Economics, Tibiscus University of Timişoara, Romania. Email: relicons@yahoo.com.

${ }^{1}$ Information available at https://ro.wikipedia.org/wiki/P\%C4\%83ianjen
} 
of the web because males have specific complex rituals of courtship, which they perform for a purpose that is greater than reproduction, that being for preventing the females from eating them after mating.

Taking that information to the business world, one can find many resemblances. The business world is made up of several entities, which act on the market and are interconnected by the business they undertake. Failure of a business can be generated by external factors independent of the manner in which the business was run, such as the level of competition or amendments to the law, as well as by internal factors that are closely connected to the abilities and professionalism of the company's management bodies. A skilful manager will protect the company against the intervention of disruptive external or internal factors, thus rendering the risks minimal. It is the same for the spiders, if the social activity distracts the manager's attention, an unfavourable situation, corroborated with the passive character of the decision makers, can lead to the dissolution of the company.

Similar to the behaviour adopted by social spiders, one can more often find now businesses organised under the form of an economic concern group, made up of several individual entities particularly meant to mitigate the shock caused on the market by the intervention of different factors.

In a perfect ecosystem, there would be a cobweb that after being built would help the spider during its entire life, without the web having to be rebuilt, but perfection is a utopia. The same stands for the perfect business network.

\section{The Insolvency Procedure in Romania}

In general, the business environment is going through continuous formation and transformation. Some players are successful, while others fail. There must be a balance between the players entering and exiting the market. The entry of new players into the market is facilitated by adequate laws, as well as the exit of those that failed in paying their debts when due.

As early as 1995, the Romanian Parliament acknowledged the importance of a Law of insolvency, as well as the need for an adequate legal framework to be in place for facilitating the recovery of the creditors' receivables by means of granting a recovery opportunity for the debtor's business, or by winding up its wealth when a reorganization of the business was no longer possible.

The constant concern displayed by the Romanian Parliament for correlating the laws to economic reality was proven by the passing of Law no. 85/2014 for the Procedures of Preventing the Insolvency, also named the New Code of Insolvency ${ }^{2}$. Even now, the Romanian Ministry of Justice is unfolding a project for improving the legal provisions for the insolvency domain, together with the National Union of Insolvency Practitioners of Romania.

The business environment of Romania is clearly affected by the insolvency of economic entities that leave the market without having met their obligations.

\footnotetext{
${ }^{2}$ Hereinafter "the New Code of Insolvency".
} 
Commercial security, which can be summarised in the creditor's confidence that they will receive payments when due, is strongly affected. A business entering into insolvency procedure indirectly affects the entire network in which it was included: its partners, customers, suppliers, and employees. Because of that in the specialist literature insolvency was compared to an epidemic ${ }^{3}$ spreading rapidly in the business environment.

The amplification of the insolvency phenomenon can be seen in the statistical data published by the National Trade Registry Office of Romania, that being the number of companies that became insolvent ${ }^{4}$, during the first quarter of 2018 which increased by $19.31 \%$ by comparison to the similar period in 2017. For understanding the whole picture of the Romanian business environment, one must mention that during January-March 2018 5,725 companies suspended their activity (an increase of $42.98 \%$ by comparison to the same period in 2017 ) and 9,793 companies were wound up (60.83\% increase by comparison to the same period in 2017) ${ }^{5}$.

De lege lata, the insolvency notion is legally defined in article 5 par. (1) item 29 of the New Code of Insolvency: "the state of the debtor's assets which is characterised by the insufficient available funds for paying the secure, liquid and payable debts."

The New Code of Insolvency mainly ensures that the debtor is granted the opportunity to recover by using the procedure for business reorganization, but it also sets out the conditions for the debtor exiting the market if they fail to repair their business - the bankruptcy procedure. One must state that, even if the New Code of Insolvency appears to be a protection granted particularly to the debtor that is unable to meet the obligations it had accepted when due, it is balanced by the rights granted to the creditors within the same procedure, who pursue the recovery of uncollected receivables.

Unfortunately, although the law comprises solid principles and rules that facilitate the reorganization of the business, its use in practice is minimal because company managers use the protection provided by the New Code of Insolvency only when the financial situation is irremediably compromised and the business activity can no longer be reorganised, therefore the bankruptcy procedure must be initiated.

\section{Opening the Insolvency Procedure - Theory}

The purpose of the New Code of Insolvency as set out in article 2, is "creating a collective procedure for covering the debtor's liabilities" while granting, when possible, the opportunity to recover their activity.

The possibility to use the insolvency procedure is open to the debtor and to the creditors, but the conditions vary. The coverage of the New Code of

\footnotetext{
${ }^{3}$ Schiau (2001) at VI.

${ }^{4}$ https://www.onrc.ro/index.php/ro/statistici?id=252

${ }^{5}$ All this statistical information is available under the form of monthly tables on the website of the National Trade Registry Office of Romania, www.onrc.ro
} 
Insolvency is very broad from the point of view of the subjects to whom it can be applied and refers to all professionals, except for those involved in liberal professions and those for which special provisions are stipulated for the status of their insolvency, such as insurance companies, banks, territorial administrative bodies or education facilities.

The law stipulates two types of procedures: a general one, in which the possibility of the debtor to recover must be analysed, and a simplified one, much shorter as regards the terms of the procedure, which involves only processing certain operations for the debtor leaving the market and deleting the business from the records of the Trade Registry. The simplified procedure applies only to the debtors that do not hold any assets in their portfolio, their memorandum of association or accounting documents cannot be found, the director cannot be found, the registered office no longer exists or the address declared to the Trade Registry Office is no longer the registered office.

If a debtor finds, according to their accounting documents, that the funds in hand are insufficient for paying the debts that had become due and payable and exigible over the previous 60 days $^{6}$, they are required ${ }^{7}$ to go before the court of law within a 30-day time period ${ }^{8}$ and submit a request for going through the insolvency procedure. It must be stated that prior to the New Code of Insolvency entering in force, the conditions described above sufficed for substantiating the opening of the insolvency procedure. After the New Code of Insolvency entered in force, the threshold value ${ }^{9}$ for opening the insolvency procedure was also set for the debtor.

Following the analysis of the possibilities for the company to recover, the debtor will decide whether opening the simplified procedure, which would lead to deleting the legal person from the records must be initiated, or the general procedure within which the reorganization of the debtor could be considered, the end being their reintegration on the market.

The debtor's request must bear their legal representative's signature and if they request that the simplified procedure be initiated, they must also submit the decision of the general meeting of the shareholders.

Several documents must be attached for the syndic judge who considers the debtor's insolvency request. They are expressly provisioned in article 66 par. (5) and article 67 par. (1) of the New Code of Insolvency.

The documents that must be attached to the request of a debtor to start the procedure are

1. Proof of notifying the competent tax body on their intention to open the insolvency procedure ${ }^{10}$;

\footnotetext{
${ }^{6}$ Article 5 par. (1) item 29 of the New Code of Insolvency defines the notion of insolvency.

${ }^{7}$ Article 66 par. (1) of the New Code of Insolvency

${ }^{8}$ Article 66 par. (1) of the New Code of Insolvency

${ }^{9}$ Article 5 par. (1) item 72 of the New Code of Insolvency defines the threshold value applicable to opening the insolvency procedure.

${ }^{10}$ Article 66 par. 1 and article 67 par. 1, letter $\mathrm{m}$.
} 
2. Last annual financial statement, trial balance for the previous month to the date of registering the petition of opening the procedure ${ }^{11}$;

3. List of the debtor's assets with the amendments in the advertising registries for those having liens, list of bank accounts where funds are transacted ${ }^{12}$;

4. List of creditors ${ }^{13}$;

5. List of payments and asset transfers made 6 months prior to opening the procedure $^{14}$;

6. Profit and loss account ${ }^{15}$;

7. List of members of the economic concern group ${ }^{16}$;

8. Declaration indicating the intent to open the simplified procedure or the general procedure ${ }^{17}$;

9. Brief description of the plans for reorganization ${ }^{18}$;

10. Notarised statement or certified declaration from an attorney at law indicating that the debtor has not undergone the reorganization procedure during the 5 years prior to submitting that request ${ }^{19}$;

11. Notarised statement or certified declaration from an attorney at law indicating that during the 5-year period prior to submitting the request, the business owners and the debtor's enforcement bodies have not been finally convicted for a series of intentional offences against assets, of corruption, forging documents, tax evasion, money laundering, etc. ${ }^{20}$;

12. Certificate of being accepted for trading on a regulated stock market or other issued financial instruments ${ }^{21}$;

13. Declaration certifying the debtor's membership in a group of companies ${ }^{22}$;

14. Decision of the General Meeting of Shareholders of the agreement for opening the simplified procedure ${ }^{23}$.

In the absence of the relevant documents the syndic judge will reject the request to open the insolvency procedure. Naturally, when one does not want to begin the reorganization of the company, the following documents must not be submitted: declaration of the plans for reorganization and notarised statements.

Summing up, it can be observed that the debtor must go through an easy initial procedure for opening the insolvency procedure, that being previously notifying the competent tax bodies (proof of notice being the document requested for opening the procedure), submitting certain accounting documents or certain

\footnotetext{
${ }^{11}$ Article 67 par. 1 letter a.

${ }^{12}$ Article 67 par. 1 letter b.

${ }^{13}$ Article 67 par. 1 letter c.

${ }^{14}$ Article 67 par. 1 letter d.

${ }^{15}$ Article 67 par. 1 letter e.

${ }^{16}$ Article 67 par. 1 letter $\mathrm{f}$.

${ }^{17}$ Article 67 par. 1 letter g.

${ }^{18}$ Article 67 par. 1 letter $\mathrm{h}$.

${ }^{19}$ Article 67 par. 1 letter i.

${ }^{20}$ Article 67 par. 1 letter j.

${ }^{21}$ Article 67 par. 1 letter $\mathrm{k}$.

${ }^{22}$ Article 67 par. 1etter 1 .

${ }^{23}$ Article 66 par. 5.
} 
lists directly deriving from the accounting documents, drafting certain simple statements and a notarised declaration.

If the request is accompanied by those documents and bears an adequate stamp, the syndic judge will issue a conclusion for opening the general or the simplified procedure. The creditors of the debtor can object to the conclusion to open the insolvency procedure in writing within a 10-day time period of receiving the notice from the insolvency practitioner who has been temporarily designated to administer the procedure.

If there is an incident that engenders the debtor's assets, the syndic judge can order the urgent interruption of any approaches to secure the debtor's assets until the time when the decision to open the insolvency procedure is issued.

The main effects of commencing the insolvency procedure affects the assets as they suspend the judicial and extrajudicial actions, stopping all ancillary amounts from accruing, interrupting the statute of the limitation period, closing the existing bank accounts and opening the sole insolvency bank account. There are also non-asset effects, such as withdrawing the debtor's right to manage the company, advertising the company's insolvency situation, ensuring that the debtor supplies the data and information requested in connection to the business activity. The existence of specific effects that could protect the assets of the company facing financial difficulties should persuade the honest debtors to use that procedure. In fact, although the debtors meet the legal conditions for lodging the petition for commencing the insolvency procedure, meaning they have debts of over 40,000 Romanian Lei, which were outstanding for over 60 days, they may remain passive and wait for the creditors wanting to recover their receivables to lodge the petition.

The creditor who is entitled to request the commencement of the insolvency procedure $^{24}$ is the company whose receivables of the debtor's assets are secure, liquid and payable for over 60 days. Secure receivables mean receivables that derive from the receivable action itself, or even from other documents, even if they are not authenticated, that are issued by the debtor or acknowledged by them. The creditor will be able to request that the insolvency procedure is initiated only if, after setting off their mutual debts, no matter their type, the amount owed surpasses the threshold of 40,000 Romanian Lei.

After the creditor has lodged his petition, the syndic judge will decide whether the conditions mentioned above were met and if so will order that the insolvency procedure is commenced or will reject the action for opening the insolvency procedure. If the receivables of the creditor that requested the insolvency procedure are paid by the date of closing the debate, the syndic judge will reject the petition as having no grounds ${ }^{25}$.

\footnotetext{
${ }^{24}$ The definition of the creditor who is entitled to request that the insolvency procedure is initiated is given in article 5 item 20 of the New Code of Insolvency

${ }^{25}$ This rule is set out in article 72 par. 5 of the New Code of Insolvency.
} 


\section{Opening the Insolvency Procedure - Practice}

Although the text of the law seems clear and straightforward, when first read, applying the legal norms mentioned above into practice has led to various difficulties and to an irregular jurisprudence.

The first issue I have found is that the debtor does not observe the due date by when they are bound to lodge a petition to begin the insolvency procedure. Article 66 par. (1) of the New Code of Insolvency states that "the debtor facing insolvency is bound to submit a petition to the court of law for having the provisions of this law applied to them in maximum 30 days of the date when the insolvency began."

If the debtors observed that legal norm, their commercial security would be enhanced and the contractual partners' trust would increase. However, this does not happen.

Any legal advisor knows that the punishment is included in the legal norms in the part that sets out the consequences that derive from not observing the norm in the circumstances by its assumption, as well as the possible approaches the competent authorities might implement against the subject of law that breached the law.

The New Code of Insolvency does not make provision for any punishment for not observing that provision, although it does indicate that the debtor is bound to submit the petition within a 30-day time frame of the date when the insolvency began. The lack of any punishment that would persuade the insolvent debtor to observe the term imposed by law has led, and is still leading, to negative effects in the business world, with commercial security thus being challenged. The Romanian debtors do not begin the insolvency procedure when financial difficulties appear and their activity could be reorganised and that is shown by the high number of bankruptcy procedures, over $95 \%$ of the total number of insolvency procedures in Romania.

When solving the matter indicated above, in connection with the regulations that will be issued, my opinion is that, while considering the obligation to lodge the insolvency petition within a 30-day time frame of the insolvency, a severe punishment must be set out, proportional to the damages brought to commercial security, such as refusing to allow the interruption of all ancillary amounts from accruing.

The second matter I am approaching refers to applying and observing article 67 par. 1 letter a of the New Code of Insolvency, which requires the debtor to attach to the petition the last financial statement and the trial balance for the month prior to the date when the petition for insolvency was registered.

Even when the petition to begin the insolvency procedure was lodged by the creditor, the debtor is bound to submit the relevant documents, among which is the summary financial statements, to the case file within a 10-day time frame $^{26}$.

\footnotetext{
${ }^{26}$ Article 82 of the New Code of Insolvency: "the debtor is bound to make available to the receiver/liquidator $[\ldots]$ all information and documents deemed necessary in connection to its activity and wealth."
} 
In practice, there are many situations when the debtor, without having any regard for the importance of the insolvency practitioner analysing their current financial situation, submits the last balance sheet registered with the finance administration with the petition to begin the insolvency procedure which is not the balance sheet of the financial period prior to lodging the petition to begin the insolvency procedure.

The activity of the insolvency practitioner implies analysing the economic activity of the debtor for at least 2 years prior to the date when the insolvency procedure began. That review is particularly important because two vital reports for the insolvency procedure are based on it: the report on the continuity of the observation period or for beginning the simplified procedure regulated by article 92 par. (1) and the report that should state the persons that contributed to the debtor's state of insolvency, which is regulated by article 97 par. (1). It sets out the need to lodge certain lawsuits ${ }^{27}$ for annulling the fraudulent documents or operations that the debtor made while damaging the creditors' rights, during the two years before the insolvency procedure was begun. Next, the report on the causes and circumstances of the grounds for the insolvency procedure, and the need to lodge the petition for determining the assets and personal liability of the persons that contributed to the debtor's insolvency, is according to article 169 of the New Code of Insolvency ${ }^{28}$.

As long as the debtor is allowed to lodge a petition for commencing the insolvency procedure by attaching "old" summarizing financial documents, while disregarding article 67 paragraph 1 letter a, which expressly requests attaching the last financial statement and the trial balance for the month prior to the date when that petition was registered to the petition to begin the procedure, it is obvious that the documents submitted have no economic or legal significance. The conclusions of the insolvency practitioner would thus be drafted only formally, without having any reliability.

In file 1776/115/2017 in the Caras Severin Court of Law, upon a creditor's request, the insolvency procedure was commenced and the only accounting documents filed were those of 2009-2011, according to which the accounting books were reviewed. Naturally, there could not be any action for annulment concerning only the operations made during the 2 years prior to the date when the insolvency procedure had been initiated or any debate on the request to determine the personal assets liability.

As long as only the syndic judge is authorised to check such documents attached to the petition for commencement of the insolvency procedure, my opinion is that such a review should not be formal, strictly limited to only checking the document named as the balance sheet. The period to which the documents attached by the debtor must be also checked. Otherwise, the entire

\footnotetext{
${ }^{27}$ The action for annulment is provisioned in the New Code of Insolvency, Tile II, Chapter I, Section 5, article 117 and the next.

${ }^{28}$ Article 169 of the New Code of Insolvency sets out the conditions and deeds, which when proven, can lead to binding the members of the debtor's management bodies to pay the debtor's obligations by using their own wealth.
} 
insolvency procedure would be led from the beginning with assumptions that are no longer real.

The third matter is construing article 72 par. 5 and par. 6, corroborated with the provisions of article 84 par. (1) of the New Code of Insolvency, which allows the debtor to pay the receivables requested by the creditor who requested to open the insolvency procedure by the time when the debates close. When the syndic judge finds that the receivables are paid, he would reject the petition for beginning the procedure and if he finds that the payment was not made until the debates were closed, he would decide on beginning the insolvency procedure. Article 84 paragraph (1) states that all documents, operations and payments made by the debtor after the date of beginning the procedure are null de jure, except for those authorised by the syndic judge or endorsed by the receiver.

The decisions given by the syndic judge are enforceable and may be challenged only by lodging an appeal. The appeal, as a manner of challenge, will begin a judicial inspection of the decision made by the syndic judge in the first instance in the court.

By means of this legal text, the debtor coming before the court of law for the commencement of the insolvency procedure has another chance to meet the obligations that he has accepted before the plaintiff who is the creditor until the debates on the merits of the case are closed.

In file $847 / 115 / 2015^{29}$ in the Caras Severin Court of Law, the syndic judge found that the creditor held secure, liquid and payable receivables of 202,058 Romanian Lei against the debtor, that the condition on the threshold value was met, and that the receivables had been outstanding for over 60 days. Given that all legal conditions were met, he ordered that the insolvency procedure should be initiated in connection with the debtor G.E. SRL. The debtor G.E. SRL lodged an appeal against the decision of the syndic judge, and the Timisoara Court of Appeal ${ }^{30}$ allowed the debtor's appeal, rejected the petition to begin the insolvency procedure and bound the creditor to pay 3,097 Romanian Lei as court costs on the consideration that until the date when the appeal was solved, the debtor had paid all of the debtor's receivables and in the accounting and financial period corresponding to the year 2014, he had registered a profit of 485,389 Romanian Lei.

A similar situation is found in file $5480 / 115 / 2016^{31}$ of the Caras Severin Court of Law. The syndic judge found that there were overdue invoices amounting to a total of 65,274 Romanian Lei out of which, during the trial on the merits of the case, 5,000 Romanian Lei were paid, but he believed that the conditions for opening the insolvency procedure in connection to S. S.R.L. were met because the receivables were secure, liquid and payable for over 60 days and over the value imposed by law of 40,000 Romanian Lei. The debtor S. SRL lodged an

\footnotetext{
${ }^{29}$ Civil decision no. 347/JS/June 11, 2015 issued for File no. 847/115/2015 of the Caras Severin Court of Law, unpublished.

${ }^{30}$ Civil decision no. 1023/November 12, 2015 issued for File no. 847/115/2015 of the Timisoara Court of Appeal, unpublished.

${ }^{31}$ Civil decision no. 405/JS/December 8, 2016 issued for the file no. 5480/115/2016 of the Caras Severin Court of Law, unpublished.
} 
appeal; the judicial inspection court ${ }^{32}$ allowed the debtor's appeal and annulled the decision that was challenged because all the receivables had been paid before the date of resolution of the appeal.

Although the New Code of Insolvency expressly provides that the procedure can be initiated in connection with the debtor who by the trial on the merits of the case had not paid the receivables, the cases presented above substantiate the possibility of paying the debts during the judgment of the appeal. It must be said that the New Code of Insolvency is a special law, which deviates from the common law.

I believe that the freedom granted to the debtors to pay the receivables to the creditor who is the plaintiff after the procedure was initiated contradicts the provisions of article 84 paragraph (1) of Law no. 85/2014, which set out the de jure nullity of any payment made after the insolvency procedure was initiated, which the syndic judge had not authorised or the receiver had not endorsed. That situation has led, as indicated in the first case, to the case of the creditor suing the debtor, who met all conditions for the commencement of the insolvency procedure, and the judicial inspection court believing that it was their fault because the debtor had paid their receivables.

In our opinion, after the insolvency procedure is initiated in the file on the merits of the case, the judicial inspection court can no longer consider subsequent payments made to the plaintiff who is the creditor, given that they are de jure null. After the insolvency procedure was initiated, the judicial inspection court should only consider the situation submitted to the syndic judge because the insolvency procedure is collective and in regard to the entire body of creditors, having strict rules on the priority of payments made to the creditors and penalising the payments made to some creditors while disregarding others. Considering the assets and non-asset effects on the debtor's wealth, the date of beginning the insolvency procedure by the syndic judge is deemed $\mathrm{T} 0$ for suspending the judicial and extrajudicial actions, stopping the ancillary amounts from accruing, suspending the statute of limitation, a matter that entitles me to believe that it applies to the payments made by the debtor without having the syndic judge's authorization or also the receiver's endorsement.

As indicated above, the decision of the syndic judge to begin the insolvency procedure is enforceable, thus the procedure follows its path with the preliminary receivables list being drafted before the appeal is judged; such a list refers to all creditors that have receivables to be collected from the debtor. Even if the judicial inspection court will consider payments made after the insolvency procedure was initiated, I believe that it cannot order that the petition be rejected just because the debtor paid the receivables to the creditor who lodged it, as long as the insolvency file also includes other creditors, who have lodged a petition to declare their receivables. For assessing whether the debtor is facing an insolvency situation after the date when the procedure was initiated by the syndic judge, it is my belief that the inspection court should look at the bigger picture, meaning

32 Civil decision no. 155/A/March 1, 2017 issued for the file no. 5480/115/2016 of the Timisoara Court of Appeal, unpublished. 
it should check whether all creditors that requested that their receivables be paid by the insolvency procedure have received their money from the debtor.

\section{Conclusion: Theory versus Practice}

The New Code of Insolvency of Romania is modern, the Parliament displaying a comprehensive insight into the manner in which the insolvency of professionals affects the business environment. If the professionals can easily enter the market, the rehabilitation of those that surpass their financial difficulties or the leaving of those that failed in meeting their obligations from the business environment is strictly controlled. Nevertheless, the New Code of Insolvency is far from being perfect. The interpretation of the law in practice varies, thus leading to an irregular jurisprudence.

More important than the various interpretations of the legal norms concerning the domain of insolvency by the law practitioners, we believe it to be a priority to educate the business environment so that it does not see insolvency as a stigma, but as an opportunity to recover that is granted to the debtors facing financial difficulties.

\section{References}

New Code of Insolvency - Law no. 85/2014 on the Procedures of Preventing the Insolvency and on the Insolvency.

Schiau, I. (2001). Regimul jurdic al insolvenței comerciale. Bucuresti: Editura All Beck.

www.onrc.ro/index.php/ro/statistici?id=252 